Children's experiencing of their transition from preschool to first grade : A visual narrative study

\title{
Salmi, Saara
}

2019-03

Salmi , S \& Kumpulainen , K 2019 , ' Children's experiencing of their transition from preschool to first grade : A visual narrative study ' , Learning, Culture and Social Interaction , vol. 20 , pp. 58-67 . https://doi.org/10.1016/j.lcsi.2017.10.007

http://hdl.handle.net/10138/326679

https://doi.org/10.1016/j.Icsi.2017.10.007

acceptedVersion

Downloaded from Helda, University of Helsinki institutional repository.

This is an electronic reprint of the original article.

This reprint may differ from the original in pagination and typographic detail.

Please cite the original version. 
Running head: CHILDREN'S EXPERIENCING OF TRANSITION: PRESCHOOL TO FIRST GRADE 1

Children's experiencing of their transition from preschool to first grade: A visual narrative study

Saara Salmi \& Kristiina Kumpulainen

University of Helsinki 


\begin{abstract}
Despite vast research on school transitions, less attention has been paid to understanding children's own sense making of their transition from preschool to first grade. Drawing on the sociocultural and dialogic approaches, this study addresses this gap by considering how visual narrative methods can illuminate children's experiencing (perezhivanie) of their school transitioning nested in the interaction between their motives and perceived demands. The data are derived from an ethnographic research project with 19 first graders aged six to seven years old attending a Finnish primary school. The children were invited to draw their transition experiences and narrate their drawings to their peers and the researchers. The visual narrations were videotaped, transcribed, and analyzed. The findings highlight the child's holistic sense making processes of their educational transitioning. The study revealed that children's motives were related to opportunities to engage in physical activities, play, make relationships, and make sense of their position and identity. The results also illuminate how the children created a subversive space for pushing the boundaries of school rules to achieve their motives. Altogether, the study demonstrates the potential of visual narrative methods in contributing to a nuanced understanding of children's experiencing of their school transitioning, including the dialogic processes of what it entails to become a "schoolchild." Keywords: school transition, sociocultural approach, dialogic approach, experiencing, motive, demand, visual narrative methods
\end{abstract}


Children's Experiencing of their Transition from Preschool to First Grade: A Visual Narrative Study

Transitioning to school is a major change in the life of a child (Forss-Pennanen, 2006; Lam, \& Pollard, 2006). It is widely recognized as a crucial phase for children's socioemotional and academic learning as well as for their healthy development in general (Chan, 2012; Wildenger \& McIntyre, 2012; Dockett \& Perry, 2007; Einarsdóttir, 2007; Hannah, Gorton, \& Jindal-Snape, 2010). When children commence primary school, they need to negotiate their participation with the new institution's values, rules, norms, and goals as well as its physical, material, and time arrangements, which often differ from those they experienced at preschool, daycare, or at home (Johnson, DeFeyter, \& Winsler, 2009; Sairanen \& Kumpulainen, 2014; Milbrath, Cameron, \& Lau, 2008; Mirkhil, 2010; Schulting, Malone, \& Dodge, 2005; Ladd, Herald, \& Kochel, 2006). In addition, school transition creates demands for children's understanding of and relationship to knowledge and their sense of selves as learners and competent actors (Rutanen \& Karila, 2013).

Despite vast research on school transitions, less attention has been paid to understanding children's own sense making of their school transitioning. It appears that the dominant focus has been on adults' perspectives and on the development of unifying and “softening” practices across transitions (see e.g., Ahtola et al., 2011; Margettsa, \& Phatudi, 2013; Rous, Hallam, McCormick, \& Cox, 2010; Skouteris, Watson, \& Lum, 2012). Drawing on the sociocultural and dialogic approaches, this study addresses this gap by considering how visual narrative methods can illuminate children's experiencing of their school transitioning nested in the interaction between their motives and perceived demands. It regards experiencing - perezhivanie - (Vygotsky, 1984) as a worthwhile and under-researched construct for investigating children's dialogic and holistic (i.e., social-cognitive-emotional) sense-making processes during school transitioning situated in a cultural-historical and 
temporal context. Our study argues that focusing on children's experiencing can contribute to a more nuanced understanding of school transitioning from the children's perspective and increase present-day understanding of what it entails to become a schoolchild. This knowledge is also important for developing educational practices that recognise children's management and negotiation of school transitions as active agents and co-participants in this process. Before describing the theoretical framing of the study, the available research on school transitioning that takes children's perspectives into account is reviewed.

\section{Children's Perspectives of Transitioning to School}

Research into children's perspectives of school transitions has revealed several discontinuities that children typically face between preschool and primary school (Corsaro \& Molinari, 2000). Existing studies have reported that children enjoy and also miss the physical and material organization of their preschool and its outdoor spaces when they transition into primary school (Clark \& Moss, 2005; Sheridan \& Pramling-Samuelson, 2001; Torstenson, 2007). Research has also demonstrated how children's expectations of school are configured by their interactions with their caregivers, other adults, and their communities. For instance, Eide and Winger (1994) showed how Norwegian preschool children's expectations of primary school reflected traditional and stereotypical views, as the children took the rules and norms of the primary school as pre-given and did not question them. Relatedly, a study by Dockett and Perry (1999b, p.117) reported that children regarded primary school "as a place where they would learn" and where it was the teacher "who made them learn." The children did not describe learning as something that they had an active role in. In all, these findings indicate how little agency children often consider themselves to have in primary school (see also Sairanen \& Kumpulainen, 2014).

It can be concluded from previous research that many children regard transitioning to school as a major change in their lives that entails several discontinuities and new demands. 
Research also shows how children's perspectives and expectations are mediated by their interactions with their communities and vary from fear and worry to excitement and opportunity (Broström, 2002, 2006; Corsaro \& Molinari, 2005). The first months in primary school are identified as being critical phases in which the continuity and discontinuity between preschool and primary school are negotiated (Dockett \& Perry, 2007; Einarsdóttir, 2002; Broström, 2003a).

The present study will add to previous research in three ways. First, it argues that, despite existing research, children's own sense making of their transition into school is not only an overlooked but also an undertheorized phenomenon. To overcome this limitation, it brings the sociocultural and dialogic approaches into focus and shows how this framing can conceptually and empirically grasp children's sense making of their school transition as a holistic and dialogic process between the child and the sociocultural context (Vygotsky, 1978, 1994). Via the dialogic framing, our study aims to shift its attention beyond the individual without losing sight of children as the active agents and subjects in culturalhistorical and temporal contexts.

Second, it emphasizes local, situated, and participant-generated definitions of what it means to transition from preschool to first grade. In doing so, we approach children's sense making with the notion of perezhivanie, commonly translated as a "lived" emotional experience examined in connection with children's changing social situation of development (Vygotsky, 1994). Specifically, it focuss on children's subjective experiencing of their transition from preschool to first grade as nested in the interaction between children's motives and experienced demands.

Third, it acknowledges that capturing the integral unity of affect and intellect of children's transition experiences in the cultural-historical and temporal contexts requires a 
sophisticated methodology. To this end, the study harnesses visual narrative methods as part of an ethnographic inquiry.

\section{Theoretical Framework}

This study is informed by the sociocultural and dialogic approaches that consider children's sense making as a dialogic process encompassing social, cognitive, affective, and personal identity dimensions within cultural contexts (Vygotsky, 1994). To theorize children's experiences as dialogic, in which human intellect, emotion, and subjective and institutional/cultural norms meet, the study draws on the concept of experiencing (perezhivanie) (Vygotsky, 1994). The concept of experiencing focuses on a dynamic tension between the given world and the way in which it is experienced. Experiencing can be viewed as dialogically configured, as individuals make sense of themselves and their experiences through symbolic forms in relation to roles, positions, and cultural imaginaries. The process of experiencing is mediated by symbolic means — not only by artifacts, but also by social institutions, practices, relationships, and geographies (Esteban \& Moll, 2014). Children's experiencing is thus configured by the ways in which emotional, intellectual, and ontological dimensions interact in cultural contexts (Bakhtin, 1994b).

The concept of experiencing, as theorized by Vygotsky (1994) and more recent scholars in socioculturally oriented research (Fleer, 2014; González Rey, 2011; Smagorinsky, 2011; Vadeboncoeur \& Collie, 2013), constitutes an interesting possibility for explaining how the same situation can be experienced in different ways by individuals across space and time; that is, how the meaning and role of the situation changes as the individual changes during development, mediated by the meanings and experiences produced through social activities and interactions within cultural practices (Vygotsky, 1994). Experiencing is thus a prominent concept with which to analyze and approach educational transition from the child's perspective across space and time. 
Following the sociocultural approach, this study proposes that children's experiencing of their lifeworlds occurs through their engagement in everyday activities that are in turn influenced by their motives and demands. Motives are culturally mediated and signify what is meaningful and important for children (Hedegaard, 2012, 2014; Fleer, 2014).

The constructs of motives and demands have been criticized for underplaying the unpredictability of human sense making and agency and stressing the influence of institutional motives, rules, and formats that guide human action. To overcome such criticisms, this dialogically informed study approaches children's motives and experienced demands as an interplay between their subjective sense making and the sociocultural context. In other words, the study attempts to uncover the individual-social and micro-macro configurations that link children's situated and subjective sense-making processes to how these are situated and constituted by their histories and cultures (Renshaw, 2004).

\section{Study}

\section{Research Questions}

1. Which motives characterize children's experiencing of their transition from preschool to first grade?

2. How do children negotiate their motives in relation to the experienced demands of first grade?

\section{Methods}

\section{Research Context}

This study draws on data from 19 first grade children aged six and seven years old attending a Finnish primary school. This data corpus is part of a year-long ethnographic study following these same children from preschool until the end of first grade (Kumpulainen \& Theron, 2013). The children's preschool and primary school were located in a suburb of Helsinki, in an area where inhabitants' education level and income were low and 
unemployment and the prevalence of city-owned rental apartments were high (Tikkanen \& Selander, 2014).

In Finland, children start preschool in the fall of the year in which they turn six and primary school in the fall of the year in which they turn seven. Finnish preschool and primary school educations differ in terms of their primary tasks and philosophical means. This is due to their different histories, and in practice, it influences the curricula and teaching methods. (Finnish National Board of Education, 2014).

\section{Data Collection}

The primary data of this study are derived from the children's visual narrations of their transition experiences. Ethical guidelines were followed by first asking permission to implement the study from the education departments of early childhood education and primary school education of the City of Helsinki. The school personnel, the children, and their parents were given information and consent forms regarding the study; the voluntary nature of participating in the study was highlighted. In this article, the children's names are pseudonyms.

Altogether, the data for this study contain children's drawings, visual narrations, and the first author's ethnographic fieldnotes from Spring 2014 to Spring 2015. The drawings and visual narration activities took place in Fall 2014 during the first semester of first grade. Specifically, the children were given paper (A3 size) and pencils and asked to draw a line down the middle. They were then asked to draw things that they related to preschool on one half of the paper and things that related to primary school on the other half. All of the children engaged in the drawing activity simultaneously in their own classrooms, and all of them drew except for one child, who wanted the researcher to write down her, that is the child's, thoughts. Two researchers, including the first author of this article, the children's first grade teachers, and the school assistants were present. 
After drawing, the children were invited to narrate their drawings to their peers and researchers. These narrations took place during the children's normal school day and were carried out in groups of two to four children. Their visual narration was held in the school building, most often in a small room used for parent-teacher meetings. During these conversations, the researchers asked the children to freely share the meanings of their drawings. To encourage the children's verbal narration of their experiencing of school transition, at times, the researchers also asked the children questions. The researchers' questions were mostly clarifying ones that invited the children to further explain their accounts. Occasionally, when the children were quiet, the researchers' questions were more leading, such as "What do you think was fun/unpleasant in preschool?" and "What do you think is fun/unpleasant in school?" Otherwise, the researchers refrained from guiding or correcting the children as they explained the meanings behind their drawings (Mitchell et al., 2011). The conversations were video-/audiotaped and later transcribed. Ethnographic field notes were used to establish a deeper understanding of the children's visual narrations, as they reflected the children's experiencing of their school transition.

\section{Data Analysis}

The data analysis of this study draws on visual ethnography (Bach, 2008; Pink, 2007) and thematic analysis of the children's narratives (Riessman, 2008). The study calls for a holistic understanding of children's visual narrations, i.e., not as detached representations of reality but as semiotic means of communication embedded in sociocultural contexts (Bach, 2008; Pink, 2007). The children's drawings, visual narratives, and the researchers' ethnographic fieldnotes together formed the unit of analysis. The analysis was holistic; hence, the focus was on the children's dialogic sense-making processes rather than on the representational drawings themselves (Light, 1985; Kress, 1997; Bach, 2008; Pink, 2007). 
In practice, the data analysis began by transcribing the video data. We read the transcripts and further sorted, categorized, and coded the data. The first stage of the analysis entailed investigating the children's visual narration in terms of topics that were brought up. This first analysis phase resulted in seven thematic categories: spaces and places, artifacts, activities, interaction with other children and adults, regulations and norms, upper grades, and "other."

In the second phase of analysis, we examined these thematic categories in terms of the children's motives and experienced demands regarding school transition. The conceptual basis of analyzing the children's motives was guided by Hedegaard's (2012) definition of young children's motives, which she defined as the child's orientation in an activity setting. To her, a child's motive orientation is made visible in his or her intentional activities and wishes.

Four categories that characterised the children's motives as evidenced in their visual narration emerged. At this stage, the first author's ethnographic fieldnotes from the children's everyday activities in preschool and first grade were exploited in order to gain a deeper understanding of the children's motives and experienced demands in their visual narratives. Moreover, to ensure validity and reliability, we analyzed the data independently, discussing the data and emerging themes throughout the analysis.

\section{Results}

The results of this study are twofold: first, it focuses on the children's motives that were made visible in their visual narrations and related discussions. Second, it illuminates how the children negotiated these motives in relation to the experienced demands of preschool and first grade.

\section{Children's Motives During School Transition}


The study revealed several motives that mediated the children's experiencing of their school transition and guided their actions and the ways in which they interacted with the environment: (a) motive for active physical engagement, (b) motive to play, (c) motive to maintain and establish interpersonal relationships, and (d) motive to make sense of their own position and identity in the school. Table 1 illustrates and defines these motives using empirical examples from the children's visual narratives. It also numerically shows how many of the children $(\mathrm{N}=19)$ demonstrated a particular motive in their visual narrations. Every child demonstrated more than one motive in his or her visual narration.

Table 1

Children's $(N=19)$ Motives Across Preschool and First Grade

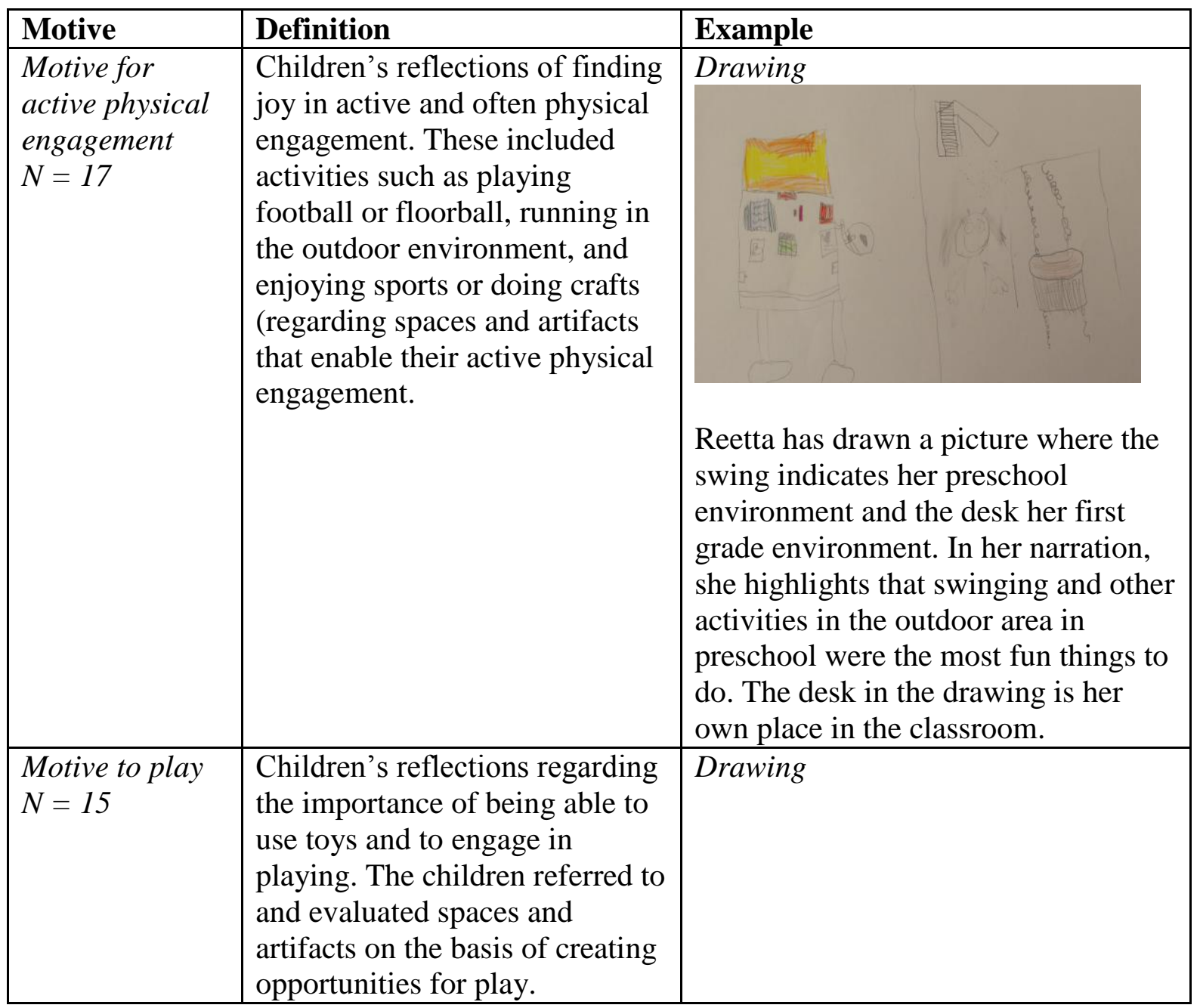




\begin{tabular}{|c|c|c|}
\hline & & $\begin{array}{l}\text { pino has drawn a picture where the } \\
\text { multiple spaces and artifacts, which } \\
\text { in her narration she highlights as } \\
\text { creating possibilities to play. The } \\
\text { seating plan refers to first grade, and } \\
\text { she recites every desk and the } \\
\text { person's name. }\end{array}$ \\
\hline $\begin{array}{l}\text { Motive to } \\
\text { establish and } \\
\text { maintain } \\
\text { relationships } \\
N=12\end{array}$ & $\begin{array}{l}\text { Children's reflections on their } \\
\text { motives to establish and } \\
\text { maintain relationships with their } \\
\text { peers and adults. The } \\
\text { meaningfulness of peer } \\
\text { relationships was highlighted as } \\
\text { the children drew and named } \\
\text { friends from preschool and first } \\
\text { grade. Transition to school was } \\
\text { also seen as an opportunity to } \\
\text { make new friends. }\end{array}$ & $\begin{array}{l}\text { Drawing } \\
\text { Sanna has drawn a picture of where } \\
\text { she is with her friend in preschool. } \\
\text { The same girl is in her current class. } \\
\text { Sanna has also drawn all of her new } \\
\text { friends on the school side. }\end{array}$ \\
\hline $\begin{array}{l}\text { Motive to } \\
\text { become, that is, } \\
\text { to make sense } \\
\text { of, own position } \\
\text { and identity in } \\
\text { the school } \\
N=9\end{array}$ & $\begin{array}{l}\text { Children's reflections on their } \\
\text { position and identity in and } \\
\text { across preschool and first grade. } \\
\text { The children reflected on their } \\
\text { past experiences in preschool } \\
\text { and envisioned their future in } \\
\text { formal school, even beyond first } \\
\text { grade. They also estimated what } \\
\text { kinds of liberties or } \\
\text { responsibilities the transition to } \\
\text { school offered them, discussing } \\
\text { whether these would be large or } \\
\text { small. }\end{array}$ & $\begin{array}{l}\text { Ella has drawn a picture of her } \\
\text { journey from home to school. She } \\
\text { highlights that the journey is short. } \\
\text { She tells that she remembers that on } \\
\text { her first day at school, her mother } \\
\text { waved at her from the window. }\end{array}$ \\
\hline
\end{tabular}




\section{Children's Visual Narrations of their Motives and Experienced Demands}

Drawing on the children's visual narrations and the ethnographic field notes collected by the first researcher, the study illuminates the ways in which the children negotiated their motives in relation to the experienced demands of preschool and first grade. The excerpts have been chosen as a result of an analytical reading of the transcripts and ethnographic field notes; the most representative examples regarding the aims of this study are included here.

Motive for active physical engagement. As the children reflected on their experiences concerning preschool, they evaluated the spatial and material opportunities they had for active physical engagement. They highlighted that the preschool environment contained indoor and outdoor spaces for various daily physical activities. These spaces included artifacts, such as rings hanging from the ceiling and swings. With regard to the school environment, it was mainly the outdoor area or indoor hall for sports where the children considered that they had the room for physical activities like running and playing football. However, some of the children stated that the school outdoor environment lacked the equipment that provoked physical functioning.

Beside spatial circumstances, the time-bound daily schedule and curriculum of the primary school also challenged the children's motive for active physical engagement. For example, they stated that in preschool, they had access to the gym hall to play football or floorball "everyday," unlike in primary school, where the curriculum controlled when the children had access to playing sports. The children described that during class, physical engagement was often prohibited, and they were expected to sit at their desks. Despite these restrictions, the children showed agency in actively searching for ways to physically engage in the school environment. Excerpt 1 demonstrates how Matti searched for ways to fulfil his motive for physical engagement in the school environment by exploiting recess. 


\section{Excerpt 1}

Researcher: Well what do you think is fun in school, what do you like to do?

Matti: Recess!

Researcher: Okay, recess. Why, what makes recess fun?

Matti: Playing football.

Researcher: What do you think, which is more fun, preschool or first grade?

Matti: I would say that preschool was more fun than first grade.

Researcher: Why?

Matti: It's fun. In preschool we got access to the gym hall! And here we don't. Only when we have sports class.

Researcher: Where do you play football when you are in school?

Matti: In the outdoor area-I always run right away to play football as recess begins. Even if someone trips me over I just stand up and continue playing.

In this excerpt, Matti shares his drawing and reflects that playing football is the most fun thing to do in school. Matti's leading motive is to engage in physical activities, especially football, and he has learned that in school, recess offers the opportunity to achieve this aim. However, Matti has presumably observed and learned that recess is a short period, and if he wishes to play for the maximum amount of time, he has to run quickly to the outside area. Matti highlights that in preschool, playing football and floorball were part of the daily schedule.

Motive to play. One of the leading motives for the children during school transition was to engage in play activities. The children had good memories of their opportunities to 
play freely together with friends in preschool, and they highlighted play and friends as being the most fun thing to do in school as well. However, as has been found in other studies, more formal teaching methods as well as stricter daily structures and schedules in primary school were something that the children felt was an obvious part of their school transition (Clarke \& Sharpe, 2003; Potter \& Briggs, 2003; Einarsdóttir, 2002). However, children actively sought opportunities to play in the school environment. As well as exploiting the daily recess for physical engagement, the children regarded recess mainly as the time and place for play (see also Dockett \& Meckley, 2007).

The transition to primary school also meant a change of artifacts, which mediated the children's activity and sense making of the environment. Regarding artifacts, toys were of great importance to the children. In their visual narrations, they reflected that the preschool environments contained plenty of toys and games, whereas desks, timetables, and instruments related to academic functions dominated the school environment. The few games that were present in school were often highlighted in the children's narrations as the most fun thing to do in school. Congruently, the children evaluated the outdoor area, both in preschool and in first grade, on the basis of the artifacts that encouraged them to play. They described that the outdoor area of the preschool consisted of artifacts like a sandbox with toys, whereas the lack of toys and hopes of having more play equipment in the school outdoor area was highlighted regarding primary school. The differences in the physical environments and the artifacts that dominated them were also evident in the children's drawings.

Despite the challenge presented by the change in the physical environment and the more formal and time-bound daily routines, the children searched for ways to fulfil their motive to play. For some, the solution was to visit their former preschool outdoor area in the evenings to play with their friends during their free time. It is notable that in this school, the children also occasionally, with the teacher's permission, get to bring toys from home to play 
with in school; this usually happens on Fridays. However, some children searched for play opportunities during other school days as well. Excerpt 2 from the group conversations demonstrates how Sami valued preschool because there, they could bring toys from home every Monday. Excerpts 3 and 4 from the first researcher's ethnographic field notes demonstrate how Sami and the other children brought toys from home despite the unwritten rule that bringing toys and playing with them during class was prohibited. Specifically, their actions demonstrate the ways in which the children can fulfil their leading objective to play in an environment with no toys and highlight how they are willing to evade the school rules.

\section{Excerpt 2}

Sami: In preschool, it was more fun because there was a day when we could bring toys to preschool. . . It was always on Mondays. One time in preschool me and my best friend brought the same toys on the same day!

\section{Excerpt 3}

Field notes 10.11.2014: Today, Sami had a toy with him in school, and the toy was in his desk. During class, Sami constantly opens his desk and plays with this toy, glancing around. Before the teacher comments on this, a boy sitting next to Sami whispers to him: "Focus on your school work!"

\section{Excerpt 4}

Field notes 19.5.2015: Today, two girls told me that one girl in their class thinks that the most fun thing in school is to bring Petshops to school in secret. The other girl, Senja, laughs and states: "I like it too." I asked her where they keep these Petshops, and Senja answers, "I keep it in my pocket." 
Motive to establish and maintain relationships. In their visual narrations, the children often reflected on their motive to establish and maintain relationships during the school transition. This result echoes previous studies in which children have underscored the importance of friends in their enculturation to school (Ladd \& Kochenderfer, 1996; Ladd \& Price, 1987). In this study, references related to relationships focused mainly on peers, but also on the relationship between the children and the teacher and/or other adults. The children reflected on their memories of their preschool teachers and how they often joined in the children's activities. The first grade teacher was defined on the basis of how strict or humorous he or she was. Excerpt 5 highlights how some of the children missed their friends from preschool, whereas others felt joy at having new friends in first grade.

\section{Excerpt 5}

Researcher: Well, what have you drawn in your picture?

Maria: This is Miisa and I (in preschool). On the other side there are Senja, Lotta, and I.

Miisa was with me in preschool, but she moved to another city. And this is an Angry Bird (a toy drawn on the school side) because Lotta and me once played with Angry Birds. I drew Senja also because she is my friend. . . I didn't have that many friends in preschool.

Researcher: Well, which one in your opinion was more fun, preschool or first grade? Lotta: Preschool! Because there I saw my best friend every day. Now I see her only on Tuesdays.

The children fulfilled their motives regarding establishing and maintaining peer relationships in creative ways in primary school. The children stated that recess was the time 
to play with friends. During classes, the children were most often expected to keep quiet and to do their schoolwork. Despite the challenges created by the schedule and the rules, the children searched for ways to negotiate these demands in order to interact with their peers. Excerpt 6 from the first researcher's ethnographic field notes demonstrates how the children overcame the formal rules of the classroom to fulfil their motive to interact with peers during class. It also demonstrates how the children searched for opportunities to function independently and control their own actions during class.

\section{Excerpt 6}

Field notes, 12.12.2014: It's maths class. The teacher tells the children to do the next spread from the math book independently as she walks around the classroom helping the children. There are sharpeners and a wastebasket in front of the class. The teacher has told the children before that if someone needs to sharpen his/her pen, they can do it there, in front of the class. First, some of the children occasionally go and sharpen their pens. Next thing I notice is that the same three boys are in front of the class quite often. I notice that when the boys return to their seats across the classroom, they smirk to each other and then they intentionally break the edges of their pens. After doing that, they go together to sharpen their pens. I can hear that the boys talk about some TV show they saw last night and are laughing. This goes on almost for the whole class.

Motive to make sense of one's own position and identity. For the children, the transition to school involved the active negotiation of their positions and identities across space and time. The children identified differences between their preschool and primary school such as the curriculum, its greater emphasis on academics, teacher-directed methods of working, and changes in their own status and responsibilities. The children actively 
reflected on their experience of becoming "pupils" with institutionally expected positions and identities. Specifically, a pupil identity meant fulfilling the expected learning objectives associated with first grade - learning to read, write, and count as well as to obey the rules of the school were seen as important parts of a "pupil identity."

The children experienced that transitioning into first grade meant an increase in restrictions. This was related to the institutional requirements of being silent during class and not being able to play or be physically active as much as they would have wished. Despite this, their visual narrations show that they experienced an increase in liberties as well. For example, it was a new liberty that in school, they could take food by themselves during lunch breaks instead of adults serving them the meal; they could also more independently arrive and leave the school. This finding adheres to previous studies of children's experiences of empowerment during transition (Loizou, 2011).

The results of this study indicate that the children's visual narrations of their transition not only concerned the moment but that the children's experiencing involved actively negotiating time in terms of their learning and academic futures. The children experienced worries regarding the institutional expectations of their learning and how they could reach them. The children were also aware that there were many more transitions ahead, and that passing one grade was obligatory in order to move to the next one. Excerpt 7 demonstrates how the children's experiencing of their school transitionin was imbued with the negotiation of time and sociocultural expectations. It also witnesses how children's sense making is mediated by other adults and peers, evidencing the dialogic nature of children's experiencing of their school transitioning within a sociocultural context.

\section{Excerpt 7}


Researcher: Imagine that there isn't that much left of this year and next it will be Christmas and by then you have already been in the first grade for almost half of it.

Sofia: And then after that we're gonna go for summer holiday and then after that I'll go to second grade!

Researcher: Well, what will it feel like to go to second grade then?

Ella: Bad. Difficult. All the assignments are difficult.

Sofia: Good. But when I go to third grade, that's not nice.

Ella: You mean fourth grade.

Sofia: Yeah, going to fourth grade is not nice. I don't ever want to go to fourth grade. 'Cause you need to dance with a boy there.

Ella: Yeah, waltz.

Researcher: Well, how do you know that?

Sofia: I've heard it from the fourth graders.

Ella: And our teacher has told [us] because she works there [in fourth grade]. And they dance there.

Sofia: Yes, and then they go somewhere and perform. I don't ever want to go to fourth grade.

In this excerpt, Ella anticipates that the second grade will be more demanding because of new school assignments; she feels that she should cope with the tasks to get to the next grade. Sofia, on the other hand, resists transitioning to fourth grade because she wants to avoid dancing with boys and performing in front of an audience. She projects this based on the information that she has gained from older students and her first grade teacher.

Although the motive to learn was not very visible in every child's narration, the children's sense making of their school transitioning was being future-oriented and linked to considering how the school can fulfill their motives across space and time. In Excerpt 8, 
Miika states that he wishes to learn English and Finnish and envisions his future in the formal school system. The same excerpt also demonstrates how the first grade's curriculum conflicts with his motive to learn things that he considers to be meaningful—in this case, English.

\section{Excerpt 8}

Miika: When we go to third grade we learn English.

Researcher: Do you think that's fun?

Miika: Yes! . . Actually, I want to go to fifth grade. I want to learn more Finnish and English.

In this excerpt, Miika elaborates on his motive to learn English and how it is not made possible for him by the first grade curriculum. For this reason, he wishes to move to upper grades where he can better fulfill his motives for learning that he considers to be meaningful. In the case of other children, the data show other motives for learning that the existing curriculum for the first grade did not appear to fulfill. These had to do with the children's motives to engage in crafts, theater clubs, and the school choir. Altogether, these results point out how children's experiencing of their school transitioning is a holistic and dialogic process between each individual child and the sociocultural context. They also show how school transitioning is not the same for each child; instead, each child views school transitioning from his or her social situation.

\section{Discussion}

Despite the vast amount of research on school transitions, less attention has been paid to understanding children's own sense making of their transition from preschool to first grade. Drawing on the sociocultural and dialogic approaches, this study has addressed this gap by considering how visual narrative methods can illuminate children's experiencing 
(perezhivanie) of their school transitioning nested in the interaction between their motives and perceived demands.

The findings of this study illuminate how children's experiencing of their school transitioning entailed active negotiation of their motives and experienced demands. The findings highlight the child's holistic sense making processes of their educational transitioning, underscoring the socioemotional, embodied and cultural nature of their experiencing. The children's motives were related to their opportunities to engage in physical and play activities, to establish and maintain relationships, and to make sense of their positions and identities. These subjective motives were the basis for their functioning and attempts to comprehend and manage the school transition. Achieving their motives was affected by the opportunities that the preschool and first grade environments offered, including how they could transform the present circumstances for their own ends. For example, for the motive of physical engagement, the children exploited daily recess as much as possible. For the motive of play, they brought toys from home because the school environment lacked artifacts with which they could play. For the motive of establishing and maintaining relationships, they exploited the formal rules of school to interact with their peers during class. For the motive of making sense of position and identity, they envisioned and gave meaning to their future identities and transitions based on their current school experiences. The study also shows how the children created a subversive space for pushing the boundaries of school rules to achieve their motives and even found fun in this activity. It seems that part of learning to become a "schoolchild" entails this kind of negotiation between subjective motives and the experienced demands of the sociomaterial environment.

In this study, the experienced demands in relation to school transition were predominantly related to the changes in the activities within the more formal, adult-directed, and academically oriented curriculum of primary school. Also, changes in the physical spaces 
and schedule created challenges for the children in achieving their motives. The children's motives were challenged because their positions and identities shifted due to their transition. These findings adhere to previous studies of children's perspectives of school transition (Broström, 2006; Corsaro \& Molinari, 2005; Dockett \& Perry, 2007; Einarsdottir, 2002, 2003, 2007a; Griebel \& Niesel, 2002).

The study demonstrates that school transition was experienced holistically and as an ongoing process established across time and space from preschool to first grade as well as in daily negotiations. The temporal aspect of experiencing became evident as the children, in their visual narrations, addressed the past and future to make sense of the present, showing their transition in relation to other events (Riessman, 1993). Overall, school transitioning appeared to create a rupture in the children's experiencing that triggered their attempts to reposition themselves in relation to the new demands of first grade (Hedegaard, 2014). However, they were not passive objects but active agents who searched for and created opportunities to establish their motives. Through their actions and motives, they attempted to influence their settings, thereby contributing to the conditions for their agency and experiencing (Hedegaard, 2014; Fleer, 2014).

Altogether, this study demonstrates the potential of visual narrative methods in contributing to a nuanced understanding of children's experiencing of their school transitioning, including the dialogic processes of what it entails to become a "schoolchild." This study suggests that visual narrative inquiry is a potential methodology for attending and listening to children and their life experiences. Visual narratives reveal the dialogic nature of children's experiencing of their school transition, that is, an interactional achievement between the child and the sociocultural context. The children's visual narrations appear to provide complex, powerful means to research and understand their experiencing across preschool and first grade (time and space) and to represent the complexity of their 
lives. The study also shows the value of visual narrative inquiry in capturing "little" but important things in children's lives that account for their experiences in and across the transition phase of starting school. The longitudinal ethnographic observation during the school transition phase greatly benefited the data interpretation and the aims of the study. The longitudinal ethnographic fieldwork, and hence knowing the children, might have had an influence on the nature of the joint conversations; the children seemed to express their emotions and thoughts more freely, and the drawings also stimulated these expressions.

This study also points out challenges in conducting visual narrative research with young children. The drawing activity encouraged the children to focus on concrete material and spatial matters, whereas more abstract, immaterial issues were not given much attention. Whether this was caused by the researchers' use of visual methods requires further research. The children also drew pictures that focused on their holiday trips, pets, or anything else that they wanted to draw at that specific moment. However, as the focus of this study was not on the drawing alone, the researchers were able to discuss their school transition without a picture that was solely focused on preschool and first grade environments or experiences during the first grade. The researchers are also aware of the power structures evident in the production of the children's visual narratives that may have influenced their accounts. As other researches have also noted, a group drawing activity and simultaneous peer narration could have potentially created a more non-confrontational basis for the activities (Einarsdóttir, Dockett, \& Perry, 2009).

\section{Conclusions}

In sociocultural theories, transition is viewed as an opportunity for children's learning and development (Vygotsky, 1998; Hedegaard \& Fleer, 2008, 2013). This developmental potential is exemplified in studies that show how children's leading motives of play change into the leading motive of learning (Elkonin, 1999; Hedegaard, 2012). This study confirms 
these conceptualizations and shows how transition from preschool to first grade and the demands of the school environment act as a developmental potential for children's learning to negotiate what it means to become "schoolchildren." This not only entails accommodating institutional practices, rules, and values, but also finding ways to fulfill their motives even if they are in conflict with the norm.

\section{Acknowledgements}

We would like to thank Anna Mikkola for her participation in the data gathering. We also thank professor Peter Renshaw for his valuable comments that significantly advanced our thinking of our study and its meaning within a dialogic approach. The research reported in this article has been funded by the Academy of Finland (project no: 1271362) and NRF (project no: 85729). 


\section{References}

Ahtola, A., Silinskas, G., Poikonen, P. L., Niemi, P., \& Nurmi, J. E. (2011).Transition to formal schooling: Do transition practices matter for academic performance? Early Childhood Research Quarterly, 26, 295-302.

Bach, H. (2008). Visual narrative inquiry. In L. Given (Ed.), The SAGE encyclopaedia of qualitative research methods. (pp. 939-941). Thousand Oaks, CA: SAGE Publications.

Bakhtin, M.M. (1994b).Speech genres and other late essays. (V. W. McGee, Trans.) Austin, TX, University of Texas Press.

Broström, S. (2002). Communication and continuity in the transition from kindergarten to school. In H. Fabian, \& A.-W. Dunlop (eds.) Transitions in the early years. Debating continuity and progression for children in early education, (pp. 52-63). London: Falmer.

Broström, S. (2003a). Problems and barriers in children's learning when they transit from kindergarten to kindergarten class in school. European Early Childhood Research Journal, Research Monograph Series 1.

Broström, S. (2006). Children's perspectives on their childhood experiences. In (eds.) J. Einarsdottir and J.T. Wagner, Nordic childhoods and early education. Philosophy, research, policy and practice in Denmark, Finland, Iceland, Norway and Sweden, Greenwich, CT: Information Age Publishing.

Chan, W.L. (2012). Expectations from the transition from kindergarten to primary school amongst teachers, parents and children. Early Childhood Development and Care, 5, 639-664.

Clark, A., \& Moss, P. (2005) Spaces to play, More listening to young children using the Mosaic approach, London: National Children's Bureau.

Clarke C., \& Sharpe P. (2003). Transition from preschool to primary school: an overview of the personal experiences of children and their parents in singapore. European Early Childhood Educational Research Journal. Themed Monograph Series 1, 15-23.

Corsaro, W.A., \& Molinari, L. 2000. Priming events and Italian children's transition from preschool to elementary school: Representation and action. Social Psychology Quarterly (1), 16-33.

Corsaro, W.A., \& Molinari, L. (2005). Compagni: Understanding children's transition from preschool to elementary school. New York, NY: Teachers College Press.

Dockett, S., \& Perry, B. (1999b). Starting school: what do the children say? Early Child Development and Care, 159, 107-119.

Dockett, S., \& Perry, B. (2007). Starting school: Perceptions, expectations and experiences. Sydney: UNSW Press.

Dockett, S., \& Meckley, A. (2007). What Young Children Say about Play at School: United States and Australian Comparisons. In: Sluss, D., J. \& Jarrett, O. (eds.) Investigating Play in the 21st Century. Lanham: University Press of America.

Eide, B. \& Winger, N. (1994). ” Du gleder deg vel til å begynnepå skolen! Oslo:Barnevernsakademiet.

Einarsdóttir, J. (2002). Children's accounts of the transition from preschool to elementary school. Barn, 4, 49-72.

Einarsdóttir, J. (2003) When the bell rings we have to go inside. Preschool children's views on the primary school, European Early Childhood Educational Research Journal. Transitions. Themed Monograph Series, 1, 35-50.

Einarsdóttir, J. (2007). Research with children: Methodological and ethical challenges. European Early Childhood Education Research Journal, 15(2), 197-211. 
Einarsdóttir, J. (2007a). Children's voices on their transition from preschool to primary school. In A.-W. Dunlop \& H. Fabian (Eds.), Informing transitions in the early years. Research, policy and practice. Maidenhead: Open University Press, McGraw-Hill.

Einarsdóttir, J., Dockett, S., \& Perry, B. (2009). Making meaning: Children's perspectives expressed through drawing. Early Child Development and Care, 179(2), 217-232.

Elkonin, D.B. (1999). Toward the problem of stages in the mental development of children. Journal of Russian and European Psychology, 37, 11-29.

Esteban-Guitart, M., \& Moll, L. (2014). Funds of Identity: A new concept based on the Funds of Knowledge approach. Culture \& Psychology, 20(1), 31-48.

Fleer, M. (2014). The demands and motives afforded through digital play in early childhood activity settings. Learning, Culture and Social Interaction, 3 (3), 202-209.

Forss-Pennanen, P. (2006). Uuden oppimista, kokeilua ja pohtimista. Yhteisöllisiä ja yksilöllisiä oppimispolkuja esi- ja alkuopetuksen yhteistyössä. Doctoral thesis. University of Jyväskylä. Faculty of Education. Chydenius-instituutti-Kokkolan yliopistokeskus. Availabe at https://jyx.jyu.fi/dspace/bitstream/handle/123456789/18017/95139-2596x.pdf? sequence $=1$

FNBE (2014). OPS 2016. Finnish National Board of Education. http://www.oph.fi/ops2016/perusteet

González Rey, F. (2011). The path to subjectivity: Advancing alternative understanding of Vygotsky and the cultural historical legacy. In P. R. Portes \& S. Salas (Eds.), Vygotsky in 21st century society: Advances in cultural historical theory and praxis with non-dominant com- munities, 32-49. New York: Peter Lang.

Griebel, W., \& Niesel, R. (2002). Co-constructing transition into kindergarten and school. In H. Fabian, H. and A.W A. Dunlop, (eds.).Transitions in the Early Years. Debating continuity and progression for children in early education. London: Routledge Falmer.

Hannah, E., Gorton, H., \& Jindal-Snape, D. (2010). ' Small steps: perspectives on understanding and supporting children starting school in Scotland '. In Jindal-Snape, D. (ed.), Educational transitions: moving stories from around the world. Routledge research in education, Routledge, Abingdon.

Hedegaard, M. (2009). Children's development from a cultural-historical approach: children's activity in everyday local settings as foundation for their development. Mind Culture and Activity, 16(1).

Hedegaard, M. (2012). Analyzing children's learning and development in everyday settings from a cultural-historical wholeness approach. Mind Culture and Activity, 19, 127-138.

Hedegaard, M. (2014). The significance of demands and motives across practices in children's learning and development: An analysis of learning in home and school. Learning, Social Interaction and Culture, 3, 188-194.

Hedegaard, M., \& Fleer, M. (2008). Studying children: A cultural-historical approach. Berkshire: Open University Press.

Hedegaard, M., \& Fleer, M. (2013). Play, learning and children's development: Everyday life in families and transition to school. New York: Cambridge University Press.

Johnson de Feyter, J., \& Winsler, A. (2009). "The early developmental competencies and school readiness of low-income, immigrant children: Influences of generation, race/ethnicity, and national origins." Early Childhood Research Quarterly, 24(4), 411-431.

Kress, G. (1997). Before Writing: Rethinking the Paths to Literacy. London: Routledge.

Kumpulainen, K., \& Theron, L. C. (2013). Social ecologies of resilience among at-risk children starting school in South Africa and Finland: A visual participatory study (SISU). Retrieved February 23, 2016, from bit.ly/21mZtqs 
Ladd, G. W., \& Price, J.M. (1987). Predicting children's social and school adjustment following the transition from preschool to kindergarten. Child Development, 58, 1168-1189.

Ladd, G.W., \& Kochenderfer, BJ. (1996). Peer victimization: cause or consequence of school maladjustment? Child Development (4):1305-17.

Ladd, G. W., Herald, S.L., \& Kochel, K.P. (2006). School readiness: Are there social prerequisites? Early Education \& Development, 17, 115-150.

Lam, Mei Suang \& Pollard, Andrew 2006. A conceptual framework for understanding children as agents in the transition from home to kindergarten. Early Years: Journal of International Research \& Development, 26(2), 123-141.

Light, P. (1985). The development of view specific representation considered from a sociocognitive standpoint. In N.H. Freeman \& M.V. Cox (Eds.), Visual order: The nature and development of pictorial representation (pp. 214-230). Cambridge: Cambridge University Press.

Loizou, E. (2011). Empowering aspects of transition from kindergarten to first grade through children's voices. Early Years, 31:1, 43-55.

Margetts, K., \& Phatudi, N. C. (2013). Transition of children from preschool and home contexts to grade 1 in two township primary schools in South Africa. European Early Childhood Education Research Journal, 21(1), 39-52.

Milbrath, C., Cameron, C.A., \& Lau, C. (2008). Family evaluation of the Welcome to Kindergarten programme. Vancouver BC: Human Early Learning Partnership. 29 pp.

Mirkhil, M. (2010). I want to play when I go to school: Children's views on the transition to school from kindergarten. Australasian Journal of Early Childhood, 35(3),134-139.

Mitchell, C., Theron, L.C., Stuart, J., Smith, A., \& Campbell, Z. (2011). Drawings as research method. L.C. Theron, C. Mitchell, J. Stuart, \& A. Smith (Eds.). Picturing research: Drawings as visual methodology (pp. 19-36). Rotterdam, the Netherlands: Sense Publishers.

Pink, S. (2007). Doing visual ethnography. London: Sage Publications Ltd.

Potter, G., \& Briggs, F., (2003). Children talk about their early experiences at school. Australian Journal of Early Childhood, 28(3), 44-49.

Renshaw, P. (2004). Introduction. Dialogic teaching, learning and instruction: Theoretical roots and analytical frameworks. In J. van der Linden, \& P. Renshaw (Eds.), Dialogic learning: Shifting perspectives to learning, instruction and teaching (pp. 1e15). Dordrecht: Kluwer Academic Publishers.

Riessman, C.K. (1993). Narrative Analysis. Qualitative Research Methods Series, No. 30.Newbury Park, CA: Sage.

Riessman, C. K. (2008) Narrative Methods for Human Sciences. Thousand Oaks, CA: Sage.

Rous, B., Hallam, R., McCormick, K., \& Cox, M. (2010). Practices that support the transition to public preschool programs: Results from a national survey. Early Childhood Research Quarterly, 25(1), 17-32.

Rutanen, N., \& Karila, K. (2013). Institutionaaliset siirtymät alle kolmivuotiaista viskareiden ja eskareiden kautta kouluun. Teoksessa K. Karila, L. Lipponen \& K. Pyhältö (toim.) Päiväkodista peruskouluun. Siirtymät varhaiskasvatuksen, esi- ja alkuopetuksen rajapinnoilla.

Sairanen, H., \& Kumpulainen, K. (2014). A visual narrative inquiry into children's sense of agency in preschool and first grade. International Journal of Educational Psychology, 3(2), 141-174.

Sheridan, S., \& Pramling Samuelsson, I. (2001). Children's conceptions of participation and influence in pre-school. A perspective on pedagogical quality. Contemporary Issues in Early Childhood, 2(2), 169-194. 
Schulting, A.B., Malone, P. S., \& Dodge, K.A. (2005). The effect of school- based kindergarten transition policies and practices on child academic outcomes. Developmental Psychology, 41(6), 860-871.

Skouteris, H., Watson, B., \& Lum, J. (2012). Preschool children's transition to formal schooling: The importance of collaboration between teachers, parents and children. Australasian Journal of Early Childhood, 37(4), 78-85.

Smagorinsky, P. (2011). Theory and method in research on literacy practices. In D. Lapp \& D. Fisher (eds.), Handbook of research on teaching the English language Arts, 3rd ed., 405-409. New York: Routledge.

Tikkanen, T., \& Selander, P. (Eds.) (2014). Helsinki By District. City of Helsinki Urban Facts. Helsinki 2014.

Torstenson, T. (2007). Children's life paths through preschool and school. Childhood, 1, 47-66.

Vadeboncoeur, J. A., \& Collie, R J. (2013). Locating social and emotional learning in schooled environments: A Vygotskian perspective on learning as unified. Mind, Culture, and Activity: An International Journal, 20(3), 201-225.

Vygotsky, L. S. (1978). Mind in society: The development of higher mental processes. Cambridge, MA: Harvard University Press

Vygotsky, L.S. (1984). Orudieiznak v razvitierebenka [The tool and the sign in child development]. In A. R. Luria \& M. Yarochevsky (Eds.), Selected works (Vol. 4, pp. 5-33). Moscow. Russia: Pedagogica.

Vygotsky, L.S. (1994). The problem of the environment. In R. V an deer Veer \& J. Valsiner (Eds.), The Vygotsky Reader (pp. 338-354). Cambridge: Blackwell.

Vygotsky, L. S. (1998). The Collected Works of L. S. Vygotsky. Vol. 5. Child Psychology. R. W. Rieber (Ed.). New York: Plenum.

Wildenger, L.K., \& McIntyre, L. (2012). Investigating the relationship between kindergarten preparation and child socio-behavioral outcomes. Early Childhood Education Journal, 169-176. 